\title{
THE CONNECTION BETWEEN PERFECTIONISM AND ANXIETY IN UNIVERSITY STUDENTS
}

\author{
Raspopovic Milena \\ Institute for Public Health, Podgorica, Montenegro
}

Primljen/Received 10. 01. 2015. god

Abstract: Introduction: Perfectionism is a relatively stable personality trait which refers to setting high personal standards and the pursuit of perfection. Anxiety as personality trait represents propensity to observe objectively harmless situations as endangering and to react signifficantly more intensive than the particular situation requires. Earlier results have shown positive correlation between exam anxiety and negative perfectionism (fear of failure). Also, some gender differences where found regarding perfectionism and anxiety, showing girls as more anxious and more perfectionists than boys.

Aim: The aim of this research was to examine if there is any correlation between perfectionism and anxiety, what is it's level and direction. Also, we wanted to examine if there are any gender differences regarding these two personality traits.

Method: Systematic non-experimental research. The study involved 202 students of Belgrade University, 158 girls (78\%) and 44 boys (22\%). Perfectionism level was measured with Multidimensional Perfectionism Scale, by Frost et al., while anxiety was measured with Enler Multidimensional Anxiety Scale - Trait. Statistical analysis included Pearson correlation and t-test of independent samples.

Results: The results show moderate positive correlation between anxiety and perfectionism $(r=0.29, p$ $=0.01$ ), and slightly higher positive correlation between anxiety and negative aspects of perfectionism $(r=$ $0.40, p=0.01)$. There is a gender difference shown in anxiety level between female and male students, i.e. Girls have shown significantly higher anxiety level than boys $\left(t=3.39, p<0.01, \eta^{2}=0.05\right)$. Regarding perfectionism, only significant gender difference was on the subdimension doubt about the action $(\mathrm{t}=2.11, \mathrm{p}=$ $0.04, \eta^{2}=0.02$ ), showing girls as more likely to express this trait than boys.

Conclusion: Based on this research we conclude that more anxious persons are more of perfectionists
Prihvaćen/Accepted 23. 11. 2015. god.

(especially negative perfectionists) than those who are less anxious. Also, our results describe female students as generally more anxious than male students.

Keywords: perfectionism, anxiety, gender differences, connection.

\section{INTRODUCTION}

Perfectionism is a relatively stable personality trait which refers to setting high personal standards and pursuit of perfection (1). Hewit and Flett (2) thought perfectionism represents striving for flawlessness, which in extreme cases extends to all aspects of life, while Burns (3) thought perfectionism in all cases of non-adaptive and undesirable traits. Today, there are also authors who strongly doubt perfectionism can be positive, healthy and functional, i.e. adaptive (1). Various authors agree that perfectionism is a stable trait, independent of the current emotional state of the person, which was confirmed by studies (1, 2, 4). Alfred Adler spoke about the innate aspiration for perfection, which is the main driving force of personality development (5). In the seventies and eighties, perfectionism was generally considered negative trait and in this period of time it was mainly associated with poor outcomes (low self-esteem, procrastination, guilt, shame and feelings of failure) or psychopathological phenomena (addictions, depression, anorexia, personality disorders) $(1,6)$. During the nineties, perfectionism was mostly described as a multidimensional construct, so accordingly, new perfectionism scales were multidimensional too $(2,7)$. Factor analysis of these tests showed that all dimensions may be reduced to two factors: one was related to positive aspirations, and the other was related to maladaptive evaluation concerns (1). Slade and Owens (8) distinguish positive perfectionism, which is the result of striving for success and negative perfectionism, which is due to fear of failure, and Hamacheck (9) cal- 
led these normal and neurotic perfectionism. Perfectionism was associated with various problems and phenomena in different studies, such as global self-esteem, depression level, demographic variables $(10,11)$. These studies showed connection between the positive aspects of perfectionism and global self-esteem (10), as well as positive correlation between negative aspects of perfectionism and depression level. It was also found that people living in the cities and those with better economic status set their personal standards significantly higher (sub dimension of positive perfectionism) (11). The same study (11) revealed gender differences regarding perfectionism, showing that girls had significantly higher scores on scales of positive perfectionism than boys (11).

Anxiety is a term used in a wide variety of meanings. It can be defined as a state of distressing and unpleasant expectations and premonition, worry and uncertainty, which lasts longer than fear, where feelings of vulnerability arise from either person's environment or person's internal conflicts and can lead to significant psychological and somatic changes (12). Spielberger's model of anxiety distinguishes state anxiety and general anxiety - anxiety as a trait. State anxiety is subjective, consciously perceived state of fear and worry associated with increased alertness of the autonomic nervous system, and can be triggered by an external or internal stimulus perceived as a danger or a threat (13). Anxiety as a trait is a tendency to perceive objectively harmless situations as threatening and to react to them much more intensively than a situation objectively requires (14). Endler's interaction model also distinguishes trait anxiety and state anxiety, but presumes their multidimensionality (15). In this study we considered anxiety as trait. Understanding anxiety is essential in understanding of either normal or pathological functioning of personality. Among other things, researchers have found negative correlation between anxiety and self-respect (14), and positive correlation between anxiety and depression (16). Anxiety may have a protective function, since it was significantly negatively correlated with the propensity to make risking decisions (17). Some studies indicate to gender differences in emotional reactions and anxiety occurrence. For instance, study (14) in a sample of young musicians showed that girls react more anxious to some stress. Very important fact for our research is the result showing positive correlation between anxiety in test situation and negative perfectionism (4).

\section{THE AIM OF THE STUDY}

The aim was to examine if there are any correlations between perfectionism and anxiety and their sub- scales, and then to determine its intensity and direction. We also wanted to examine if there are any gender differences regarding these two personality traits.

\section{METHOD}

This was a systematic non-experimental research. We collected data through questionnaires in Belgrade in October and November 2013. The survey was conducted on a sample of Belgrade University students. Of 202 students 158 or $78 \%$ were girls and 44 or $22 \%$ were boys.

To estimate perfectionism level we used Multidimensional Perfectionism Scale (MPS), constructed by Fost and associates, and translated to Serbian and adapted by Stojiljković and Maksić (18). The coefficient of reliability of the total score, measured by the authors, was 0.90 , and the reliability of subscales from 0.77 to 0.93 . The instrument contains 35 claims and the task of respondents is to check the degree of agreement with the statement on a five-point Likert scale. Information gathered on this scale tells us about the total perfectionism level and its subdimensions. The scale includes the following subscales: concern over mistakes, personal standards, parental expectations, parental criticism, doubts regarding action and organization. The authors have conducted factor analysis, which showed that personal standards and organization may be considered subdimensions of positive perfectionism, and concern over mistakes, parental expectations, parental criticism, as well as doubts concerning the action as dimensions of negative perfectionism (7). Higher scores on MPS indicate higher perfectionism.

Anxiety level was estimated using Endler Multidimensional Anxiety Scale - Trait (EMAS-T). Scale refers to anxiety as a trait and it was constructed by the Endler and associates as one of the three parts of Endler's Multidimensional Anxiety Scales, in addition to the scale relating to anxiety as a state (EMAS -S) and scale related to the perception of the type and intensity of the threat posed by specific situation (EMAS - P). EMAS-T scale consists of four subscales: social evaluation/assessment, physically dangerous situations, new/unfamiliar situations and everyday situations. Each subscale consists of 15 items where respondents on the Likert five point scales assess the extent to which data statement describes their reactions and attitudes in thus defined situations. The scales were translated into Croatian and adapted by Sorić and associates (19). Higher scores on EMAS - T indicate higher anxiety.

The data were analyzed in SPSS 20.0 (Statistical Package for the Social Sciences). Method of linear correlation - Pearson coefficient examined interconnection between the dimensions of perfectionism and anx- 
iety. Method t-test for independent samples examined differences between the sexes in terms of perfectionism and anxiety level.

\section{RESULTS}

\section{Perfectionism and anxiety}

Pearson's correlation coefficient between the total scores on the scales EMAS-T and MPS is 0.29 and is statistically significant at the level of 0.01 (Table 1). The correlation between anxiety and negative perfectionism is something greater and statistically significant, also on level 0.01 . The statistically significant correlation between positive perfectionism and anxiety was not ascertained.

Total perfectionism significantly positively correlated with anxiety in assessment situations and anxiety in new situations scales (Table 2). There were no signi-

Table 1. Correlation (Pearson's r) between anxiety and general perfectionism, positive perfectionism and negative perfectionism

\begin{tabular}{|c|c|}
\hline & Anxiety \\
\hline Perfectionism (general) & $0.29 * *$ \\
\hline Positive perfectionism & -0.07 \\
\hline Negative perfectionism & $0.40^{* *}$ \\
\hline
\end{tabular}

** significant at the 0.01 level

Table 2. Correlation (Pearson's r) between perfectionism and four subscales of anxiety (of EMAS-T)

\begin{tabular}{|c|c|}
\hline Anxiety in assessment situations & $\begin{array}{c}\text { Perfectio- } \\
\text { nism }\end{array}$ \\
\hline Anxiety in situations of physical danger & $0.27^{* *}$ \\
\hline Anxiety in new situations & 0.08 \\
\hline Anxiety in everyday situations & 0.13 \\
\hline
\end{tabular}

** significant at the level 0.01

EMAS-T: Endler Multidimensional Anxiety Scale - Trait ficant correlation between perfectionism and anxiety in situations of physical danger and anxiety in everyday situations. Therefore, bigger perfectionists are more prone to show anxiety in assessment and unfamiliar situations.

From Table 3, we see that there were no significant correlation between positive perfectionism and any of anxiety subscales. Negative perfectionism correlated significantly and positively with anxiety in situations of assessment with 0.48 correlation coefficient (Pearson's r), while the correlation with anxiety in new situations and anxiety in everyday situations is somewhat lesser, but also statistically significant and positive.

As for the correlation between the four types of anxiety and six subdimensions of perfectionism, it should be emphasized that the organization as subdimension of positive perfectionism significantly negatively correlated with anxiety in everyday situations (Pearson's $\mathrm{r}=-0.28)$.

\section{Gender and perfectionism}

The only statistically significant gender difference in terms of the dimensions of perfectionism was obtained on the dimension doubt about the action. Here the value of $t$ statistics is 2.11 and it is significant at the 0.05 level. Thus, according to our results, girls significantly more express this trait than boys. To determine what is the size of the gender effect on the expression of doubt about the action we calculated eta squared, and it is 0.02 , which indicates a rather small influence of gender on the expression of doubt about the action.

\section{Gender and anxiety}

When it comes to anxiety, it was shown that there are differences between boys and girls, both in terms of general anxiety trait, where the value of the $t$ statistic is $3.39(\mathrm{p} \leq 0.01)$, and the eta - squared of 0.05 . The situation is similar when it comes to subdimensions of anxiety, except the anxiety in everyday situations. These

Table 3. Correlations (Pearson's r) between positive and negative perfectionism and anxiety subscales (of EMAS-T)

\begin{tabular}{|c|c|c|c|}
\hline & $\mathrm{r}$ & & $\mathrm{r}$ \\
\hline $\begin{array}{c}\text { Pos. Perfectionism - Anxiety in } \\
\text { assessment }\end{array}$ & -0.10 & $\begin{array}{c}\text { Neg. Perfectionism - Anxiety in } \\
\text { assessment }\end{array}$ & $0.38^{* *}$ \\
\hline $\begin{array}{c}\text { Pos.Perfectionism - Anxiety in situations } \\
\text { of physical danger }\end{array}$ & 0.09 & $\begin{array}{c}\text { Neg. Perfectionism - Anxiety in } \\
\text { situations of physical danger }\end{array}$ & 0.05 \\
\hline $\begin{array}{c}\text { Pos. Perfectionism - Anxiety in new } \\
\text { situations }\end{array}$ & -0.02 & $\begin{array}{c}\text { Neg. Perfectionism - Anxiety in new } \\
\text { situations }\end{array}$ & $0.25^{* *}$ \\
\hline $\begin{array}{c}\text { Pos. Perfectionism - Anxiety in everyday } \\
\text { situations }\end{array}$ & -0.14 & $\begin{array}{c}\text { Neg. Perfectionism - Anxiety in everyday } \\
\text { situations }\end{array}$ & $0.23^{* *}$ \\
\hline
\end{tabular}

** significant at the level 0.01

EMAS-T: Endler Multidimensional Anxiety Scale - Trait 
significant differences speak in favor of anxiety being more prominent in girls than in boys. Calculated eta squared points to a moderate size of the influence of gender on the presence of anxiety.

\section{DISCUSSION}

Our research has confirmed the existence of a positive correlation between perfectionism and anxiety in general, but also between their subdimensions. Total perfectionism was significantly positively associated with anxiety in assessment situations and new/unfamiliar situations. Slightly higher correlation than in the case of general perfectionism was found between negative perfectionism and overall anxiety, which is consistent with the results obtained in earlier studies (4). This connecttion between anxiety and negative aspects of perfectionism is particularly evident in assessment situations, unfamiliar and everyday situations. Thus, students who tend to display anxiety in these situations are persons who are more likely to show indicators of negative perfectionism than others. Only in the case of manifestation of anxiety in situations of physical danger there were no relationship between the level of the negative perfectionism aspect. Although we haven't found significant relationship between general anxiety and positive perfectionism, we found a significant negative correlation between organization and anxiety in everyday situations. Speaking common sense, it is expected that the less organised people will be more likely to feel anxious in everyday situations.

In contrast to the results of previous studies (11), where it was found that girls had significantly higher scores on scales of positive perfectionism than boys, we did not find a significant difference between boys and girls in terms of general perfectionism. The only indication of perfectionism which is more pronounced in girls is the tendency to have doubts about taking some action, although the intensity of the impact of gender on this feature is not particularly large $(\mathrm{p}<0.05$, eta squared $=0.02$ ). So, we can only conclude that the girls in terms of taking some action or initiation of dealing with something and somewhat are more thoroughly and more punctilious, but also indecisive and more prone of reluctance than boys. When it comes to the presence of anxiety, it was shown that it is significantly more expressed in female and this is true for general anxiety, and also anxiety in the assessment situations, anxiety in physically dangerous situations and anxiety in new/unfamiliar situations. This is consistent with results of previous studies (14), where on a sample of young musicians researchers have found that girls show significantly higher levels of anxiety than boys.

\section{CONCLUSION}

We examined the connection between perfectionism and anxiety in a sample from the student population, as well as gender differences in the expression of these two personality traits. The results of this research confirmed that these two traits are moderately positively correlated with each other. Therefore, we can conclude that the anxious persons are generally more of perfectionists, especially of a people who express negative aspects of perfectionism, which are thought to arise as a consequence of the fear of failure. It was found that female students are generally more anxious thane male students. In terms of perfectionism, girls showed significantly higher level of doubt about the action.

\section{DECLARATION OF INTEREST. None}

\section{Abbreviations}

MPS - Multidimensional Perfectionism Scale

EMAS-T - Endler Multidimensional Anxiety

Scale - Trait

EMAS-S - s-endler multidimensional anxiety scale - state

EMAS-P - p-edler multidimensional anxiety scale - perception of the threat

\title{
Sažetak
}

\section{POVEZANOST PERFEKCIONIZMA I ANKSIOZNOSTI KOD STUDENATA}

\author{
Raspopovic Milena \\ Institut za javno zdravlje, Podgorica, Crna Gora
}

Uvod. Perfekcionizam je relativno stabilna osobina ličnosti koja podrazumeva postavljanje visokih ličnih standarda i težnju ka savršenstvu. Anksioznost posmatrana kao crta ličnosti predstavlja sklonost da se situacije koje su objektivno bezopasne opažaju kao ugrožavajuće i da se na njih reaguje znatno intenzivni- je nego što to situacija objektivno nalaže. Raniji rezultati pokazuju da je anksioznost u ispitnoj situaciji u pozitivnoj vezi sa negativnim perfekcionizmom (strahom od neuspeha). Takođe, ranija istraživanja pokazuju da postoje razlike između polova u pogledu izraženosti ovih osobina, u oba slučaja u korist devojaka. 
Cilj. Cilj istraživanja bio je da se ispita da li postoji povezanost između perfekcionizma i anksioznosti, kakvog je intenziteta i smera. Pored toga, želeli smo da ispitamo postoje li razlike između polova u pogledu izraženosti ove dve osobine ličnosti.

Metod. Sistematsko neeksperimentalno istraživanje. Uzorak je činilo 202 studenta Beogradskog Univerziteta, od toga 158 devojaka (78\%) i 44 mladića (22\%). Izraženost crte perfekcionizma merena je testom Multidimenzionalna Skala Perfekcionizma, Frosta i saradnika, dok je anksioznost merena testom Endlerova Multidimenzionalna Skala Anksioznosti - Crte. Statističke tehnike koje smo koristili u analizi su Pirsonov koeficijent korelacije i t-test nezavisnih uzoraka.

Rezultati. Rezultati pokazuju umerenu pozitivnu korelaciju anksioznosti sa ukupnim perfekcionizmom $(\mathrm{r}=0.29, \mathrm{p}=0.01)$, kao i nešto intenzivniju, takođe po-

\section{REFFERENCES}

1. Stoeber J, Otto K. Positive conceptions of perfectionism: Approaches, evidence, challenges. Pers Soc Psychol Rev. 2006; 10(4): 295-319.

2. Flett GL, Hewitt PL. Perfectionism: theory, research and treatment. Washington, DC: APA, 2002.

3. Burns DD. The perfectionist's script for self-defeat. Psychology Today.1980; 14(6): 34-52.

4. Erceg Jugović I, Lauri Korajlija A. Povezanost ispitne anksioznosti s perfekcionizmom. Psihologijske teme. 2012; 21(2): 299-316.

5. Ansbacher HL, Ansbacher RR. The individual psychology of Alfred Adler. Oxford, England: Basic Books, Inc., 1956.

6. Hewitt PL., Flett GL. Perfectionism in the self and social contexts: Conceptualisation, assessment, and association with psychopatology. J Pers Soc Psychol. 1991; 60(3): 456-70.

7. Frost RO, Marten P, Lahart C, Rosenblate R. The dimensions of Perfectionism. Cognitive Therapy and Research, 1990; 14(5), 449-68.

8. Slade PD, Owens RG. A dual process model of perfectionism based on reinforcement theory. Behav Modif. 1998; 22(3): 372-90.

9. Hamachek DE. Psychodynamics of normal and neurotic perfectionism. Psychology: A Journal of Human Behavior.1978; 15(1): 27-33.

10. Todorović D, Zlatanović Lj, Stojiljković S, Todorović J. Povezanost perfekcionizma sa samopoštovanjem i depresivnošću kod studenata. Godišnjak za psihologiju. 2009; 6(8): 173-84.

\section{Correspondence to /Autor za korespondenciju}

Milena Raspopović

milena.mea.86@gmail.com

$+382679132020$ zitivnu, korelaciju anksioznosti sa negativnim aspektima perfekcionizma $(r=0.40, p=0.01)$. Nađena je razlika između polova u pogledu anksioznosti, tj. da je kod studentkinja anksioznost značajno više izražena nego kod muških studenata $(\mathrm{t}=3.39, \mathrm{p}<0.01,=0.05)$. Kada je u pitanju perfekcionizam, jedina značajna razlika između polova nađena je u pogledu subdimenzije sumnja i vezi akcije $(\mathrm{t}=2.11, \mathrm{p}=0.04,=0.02)$, koja pokazuje da je ova crta izraženija kod devojaka nego kod mladića.

Zaključak. Dakle, na osnovu ovog istraživanja mogli bismo zaključiti da su anksioznije osobe uglavnom i veći perfekcionisti (pogotovo negativni perfekcionisti) nego manje anksiozne osobe, kao i da su studentkinje generalno anksioznije od studenata.

Ključne reči. perfekcionizam, anksioznost, pol, povezanost.

11. Opsenica-Kostić J, Panić T. Perfekcionizam srednjoškolaca - povezanost sa nekim socio-demografskim varijablama. Godišnjak za psihologiju. 2006; 4(4-5): 143-58.

12. Erić Lj. Strah, anksioznost i anksiozna stanja. Beograd: Institut za stručno usavršavanje i specijalizaciju zdravstvenih radnika, 1972.

13. Spielberger CD. State-Trait Anxiety Inventory: Bibliography. $2^{\text {nd }}$ ed. Palo Alto, CA: Consulting Psychologists Press, 1989.

14. Anđelković V. Anksioznost i samopoštovanje u kontekstu uzrasta, pola i profesionalnog usmerenja. Godišnjak za psihologiju. 2008; 5(6-7): 111-30.

15. Endler, NS., Edwards JM, Vitelli R. Endler multidimensional anxiety scales (EMAS). Los Angeles, CA: Western Psychological Services, 1991.

16. Vulić-Prtorić A, Macuka I. Anksioznost i depresivnost - fenomenologija komorbidnosti. Suvremena psihologija. 2004; 7(1): 45-64.

17. Kirsch M, Windman S. The role of anxiety in decision-making. Review of Psychology. 2009; 16(1): 19-28.

18. Stojiljković S, Todorović J, Dosković Z, Todorović D. Razlike u perfekcionizmu srpskih i makedonskih studenata. Zbornik instituta za pedagoška istraživanja. 2011; 43(2): 321-9.

19. Sorić I. Endlerove multidimenzionalne skale anksioznosti. U: Grgin K.L. i sar. (urednici). Zbirka psihologijskih skala i upitnika. Zadar: Filozofski fakultet, 2002: 115-23. 